PART 2

Modes 
Mario Infelise - 9789004277199

Downloaded from Brill.come4/26/2023 03:29:56PM via free access 


\title{
The History of a Word: Gazzetta / Gazette
}

\author{
Mario Infelise
}

The term gazette and its variants in some of the European languagesgazzetta in Italian, gazette in French and English, gaceta in Spanish, gazetten in German, though this is less common-defined a new medium of information which developed in Europe between the sixteenth and seventeenth centuries. The goal of this chapter is to try and reconstruct the history of this word until 1631, when it became the title of the most important printed newssheet of the Kingdom of France and assumed its current meaning. This could offer a different approach to the evolution of the phenomenon of public information in the early modern age, able to explain some interesting aspects of its development.

My aims are as follows: first, to deconstruct the etymological history of the term gazzetta, beginning with contemporary dictionaries; and second, to establish the differences between the respective systems of the gazzetta and the avviso. It should be remembered that the system of avvisi existed from at least the fifteenth century, but was mostly the concern of courts and princes, and political and religious circles more generally. On the other hand, the gazettes, as we will see, bring about the emergence of a new public. My examinations of both terms exclusively concern only handwritten newsletters which supplied news on a regular basis. As is well known, the printing of gazettes is a phenomenon that began in the first decades of the seventeenth century, but was not in itself particularly innovative. At that time, there was already an intense circulation of handwritten newssheets in Europe.

\section{Etymological History}

The entries in all of the most important dictionaries of European languages of the twentieth century give the same etymology. For example, the entry gazette in the French dictionary Grand Larousse suggests the following origin:

GAZETTE: ital. gazzetta, gazette empr. du vénitien gazeta, feuille périodique donnant des informations sur les affaires commerciales de Venise, ainsi que sur les événements du temps, et coutant une gazeta, c'est-à-dire environ trois liards, le nom de la pièce de la monnaie [dimin. de gazza, 
'monnaie' term de meme racine que le franç. geai ...] ayant été donné à objet qu'elle permettait d'acheter ... ${ }^{1}$

([Gazette:, ital. gazzetta, gazette, borrowed from Venetian gazeta, periodical sheet giving news of commercial affairs in Venice, as well as current events, and costing one gazeta, (which is to say about three liards) the name of the coin itself [diminutive of gazza, 'coin', with the same root as the French 'geai'] being given to the object it allows one buy.)

In the foremost Italian language dictionary - that of Salvatore Battaglia - the term gazzetta derives from: "Gazzetta in quanto la Gazeta de le novità costava a Venezia una gazzetta" ("Gazzetta [in the sense of the coin] in that the Gazeta de le novità cost a gazzetta in Venice"). ${ }^{2}$ The Venetian origin of the word is confirmed in the Oxford English Dictionary, which draws on the sixteenth-century linguist and lexicographer John Florio, who will be discussed in more detail below:

The gazzetta was first published in Venice about the middle of the sixteenth century, and similar news-sheets appeared in France and England in the seventeenth. The untrustworthy nature of their reports is often alluded to by writers of that period; thus Florio explains gazzette as "running reports, daily newes, idle intelligences, or flim flam tales that are daily written from Italie, namely from Rome and Venice". ${ }^{3}$

Going back further in time, the information furnished by nineteenth-century dictionaries tells a similar story. See, for example, the etymology supplied by the French dictionary of Emile Littré, published between 1872 and 1877:

GAZETTE: espagn. gazeta; ital. gazzetta; d'après Ménage et Ferrari, du vénitien gazzetta, nom d'une petite monnaie que coûtait le papier-nouvelle vendu à Venise; le nom de la pièce de monnaie passa au journal. D'autres ont dit que gazzetta était le diminutif de gazza, pie. M. Garcin de Tassy le tire de l'indo-persan kâged ou kâgiz, papier. Mais c'est l'opinion de Ménage

1 Grand Larousse de la langue française (Paris: Larousse 1986), vol. 3, p. 2174.

2 See the item Gazzetta in Salvatore Battaglia, ed., Grande dizionario della lingua italiana, 21 vols. (Turin: Unione tipografico-editrice torinese, 1961-2002), 6: 624 .

3 Oxford English Dictionary, ed. J.A. Simpson and E.S.C. Weiner (2nd ed.; Oxford: Oxford University Press, 1989). 
et de Ferrari qui doit prévaloir; du moins un des exemples de d'Aubigné prouve que gazette était alors le nom d'une monnaie. ${ }^{4}$

([Gazette: espagn. gazeta; ital. Gazzetta: according Ménage and Ferrari, from the Venetian gazzetta, the name of a small coin which was also the price of a paper of news sold at Venice; the name of the coin transferring to the newspaper. Others suggest that gazetta was the diminutive of gazza, pie. Mr Garcin de Tassy derives this from the Indo-persian kâged or kâgiz, meaning paper. But it is the opinion of Ménage and Ferrari that ought to pravail; at least one of the examples supplied by D'Aubigné proves that gazette was indeed the name of a coin.)

Gazette would therefore seem to be a word of Venetian origin, used to indicate a newssheet, and its name to derive from a coin that was equivalent to the cost of the newssheet. Is this a plausible explanation? And what are the sources of these modern dictionaries?

I will begin with the second question. Probably the most important source for all contemporary dictionaries is Voltaire's article 'Gazette' in Denis Diderot and Jean D'Alembert's Encyclopédie:

GAZETTE, s. f. (Hist. mod.) relation des affaires publiques. Ce fut au commencement du XVIIe siècle que cet usage utile fut inventé à Venise, dans le tems que l'Italie étoit encore le centre des négociations de l'Europe, \& que Venise étoit toûjours l'asyle de la liberté. On appella ces feuilles qu'on donnoit une fois par semaine, gazettes, du nom de gazetta, petite monnoie revenante à un de nos demisous, qui avoit cours alors à Venise. Cet exemple fut ensuite imité dans toutes les grandes villes de l'Europe. ${ }^{5}$

(Gazette ... an account of public affairs. This useful custom was invented at Venice in the beginning of the seventeenth century, when Italy was still the centre of European commerce and Venice still the refuge of freedom. These sheets, issued once a week, were known by the name of gazettes,

4 Émile Littré, Dictionnaire de la langue française, 4 vols. (Paris: Hachette, 1874), 2: 1847. The citation of Theodore d'Aubigne to which Littré refers is from Histoire universelle depuis 1550 jusqu'en 1601 (Amsterdam, 1626), vol. 3, p. 51: "Il se retira en cette ville (qui estoit Venize) au mois de juin an susdit [1598], n'aiant avec lui qu'une seule gazette, piece de monnoie valant trois liards de France".

5 Encyclopédie, ou Dictionnaire raisonné des sciences, des arts et de metiers, 28 vols. (Paris: André le Breton, Michel-Antoine David, Laurent Durand, Antoine-Claude Briasson, 1757), 7: 534-5. 
from the word gazetta, a small coin equivalent to one of our demisous, then current at Venice. This example was then imitated in all the great cities of Europe.)

Voltaire's main source of information was Ephraim Chambers' Cyclopedia, published in London in 1728 , which added other hypotheses to the usual etymologies which the compiler considered quite improbable:

GAZETTE, a News Paper, or printed account of the transactions of divers countries, in a loose sheet. Thus we say, the London Gazette, Paris Gazette, Gazette a la main, \&cc.

Gazettes, which most people look on as triffles, are really the most difficult kind of compositions that have appear'd. They require a very extensive acquaintance with the languages, and all the terms thereof; a great easiness and command of writing, and relating, things cleanly, and in a few words.

To write a gazette, a man should be able to speak of war both by land and sea; be thoroughly acquainted with every thing relating to geography, the history of the time, and that of the noble families; with the several interests of princes, the secrets of courts, and the manners and customs of all nations.

Vigneul de Marville recommends a set of gazettes well wrote, as the fittest books for the instruction of young persons, coming into the world.

The word is form'd of Gazetta, a kind of coin, formerly currant at Venice; which was the ordinary price of the first news papers printed there: tho' others derive it by corruption from the hebrew Izgad, which signifies Nuntius, a messenger; but this etymology is too much forced, and the former ought to be preferred.

The first Gazette publish'd in these parts, is said to be that of Paris, begun in the year 1631 by Theophrast Renaudot, a physician of Montpellier, in his office of intelligence. See INTELLIGENCE. ${ }^{6}$

One must go back to the 1670 s to finally track down the origin of this etymology. Two frequently quoted histories of the Italian tongue explain the relationship between the coin and the printed newssheet. In 1676 , the Italian scholar Ottavio Ferrari wrote that gazzetta was the name of a Venetian coin and that this name had subsequently been adopted for the newssheets. ${ }^{7} \mathrm{~A}$ few years

6 Ephraim Chambers, Cyclopeedia, or, An universal dictionary of arts and sciences (London, 1728), entry Gazette.

7 Ottavio Ferrari, Origines linguae italicae (Padova: Pietro Maria Frambotti, 1676), p. 156. 
later a Frenchman, Gilles Ménage took up this definition and added yet another curious detail: "that he had often heard said by a gentleman that these sheets had taken the name of this coin because in the past this had been the price demanded from those who bought gazettes".

We do not know anything about this 'gentleman', but it is possible that the relationship between the coin and the newsletters was introduced, as we shall later see, by the second edition of John Florio's Italian-English dictionary in 1611 in which we find two distinct entries: gazzetta, in the singular for coins; and gazzette in the plural for newsheets. It is also apparent in the contemporaneous English-French dictionary by Randle Cotgrave, whose entry for Gazette reads as follows:

GAZETTE: A certaine Venetian coyne scarce worth our farthing; also a bill of newes or a short relation of the generall occurrences of the time, forged most commonly at Venice and thence dispersed every month into most parts of Christendome. ${ }^{9}$

It is interesting to note that these articles of 1611 record for the first time the existence of a Venetian coin called gazzetta, even if it does not establish a direct connection between the coin and the newsletters.

I will now proceed to verify if a coin called gazzetta / gazetta really existed and if this relationship between the coin and the newsletters can be dated with any precision.

\section{The Coin}

It has been substantiated that, at least after 1515, a low-denomination coin was in circulation both in Venice and Cyprus, and that after $155^{\circ}$ this coin was referred to as a gazzetta in official documents. This use continued for some time. In the first half of the twentieth century, the name was still in use in the Greek dialect of the sometime Venetian Ionian isles, to indicate a coin of

8 Gilles Ménage (Egidio Menagio), Le origini della lingua italiana (Geneva, 1685), p. 247. Years before in his Origines de la langue française (Paris, 1650), p. 345; for the entry Gazette, Ménage was limited to writing: "De l'Italien Gazetta qui signifie proprement une espece de monnoye de Venise et pour laquelle on avoit le cahier des nouvelles courantes. Depuis on a transporté ce nom au cahier mesme".

9 Randle Cotgrave, A Dictionarie of French and English Tongues (London, 1611). 
$10 \lambda \varepsilon \pi \tau \dot{\alpha}$, the lowest amount in circulation..$^{10}$ Less easy to establish is the exact meaning and origin of this word. It has been written that it could derive from medieval Latin because in the dictionaries we find the word Gazetum with the meaning of Gazarum repositorium, a place designed to hold treasure." It derives from the greek term gaza $\gamma \alpha \dot{\alpha} \alpha$, which means treasure, treasury, wealth. ${ }^{12}$ In turn, $\gamma \alpha \dot{\zeta} \zeta \alpha$ derives from the Persian gazna-, ganźa-, ganja, which have the same meaning. ${ }^{13}$ Ancient history is not clear. The word would have been diffused, probably via Middle Iranian sources, into various languages by means of other Iranian languages through the settling of Achaemenid officials in Semitic, Greek and Indian territories.

This explanation, however, is unlikely in this context. In any case, the most probable origin has a closer link to the Venetian currency. It is certain that on 14 October 1515, a decree by the Venetian Council of Ten arranged for the manufacturing of 1,00o carzie - coins of little value - to be sent to the island of Cyprus, where there was already a coin of the same name in circulation. The diarist Marin Sanudo called the same coin a garzia in $1518 . .^{14}$ The gazzetta would therefore be a diminutive of the Venetian variation of the word, further legitimised by the low value of a coin which contained more copper than silver. In addition, Greek etymology makes specific reference to this particularity: $\chi \alpha p \xi 1 \alpha$, derives in turn from $\chi \alpha \lambda$ xós (copper). There is one more hypothesis: the Greek word was imported to the East by the Franks and derived from the German Kreuzer, since one of the coin's faces bore an image of a cross. ${ }^{15}$

10 Nicolò Papadopoli Aldobrandini, Le monete di Venezia (Venice, 1893-1919), vols. 2-3 ad indices. Paulos Lampros, Coins and medals of the Ionian Islands (Chicago: Argonaut, 1968), p. 16.

11 Charles Du Fresne Du Cange, Glossarium ad scriptores mediae et infimae latinitatis (Basel, 1752), vol. 2, part 1, p. 467.

12 Pierre Chantraine, Dictionnaire étymologique de la langue grecque (Paris: Klincksieck, 1968-80), p. 206: "tresor royal, tresor. (OG I 54,22, IIIe s. av., Thphr., LXX, NT, etc.) employé par Plb. pour une grosse somme d'argent. Comme premier terme dans les composes: $\gamma \alpha \zeta \circ \varphi \dot{\nu} \lambda \alpha \xi$ «gardien du tresor » (LXX, Str., etc.), - $\varphi v \lambda \alpha \alpha \varepsilon \dot{\varepsilon} \omega$ (D.s.), - $\varphi v \lambda \dot{\alpha} x 10 v$ « tresor » (OGI 225,16, IIIE s. av., LXX, NT, Str.). Et: D’apres Pom Mela 1,64, emprunt au perse; on rapproche m. perse ganj, etc.;le lat. gaza est emprunte au grec de meme que, probablement, syr. Gazā".

13 D.N. MacKenzie, A Concise Pahlavi Dictionary (London: Routledge, 1971), p. 35; V.S. Rastorgueva-D.I. Ėdel'man, Ėtimologičeskij slovar' iranskich jazykov (Moscow: Vostočnaja Literatura, 2007), vol. 3, pp. 258-9. Many thanks to my colleague Riccardo Zipoli for his suggestions on Persian dictionaries.

14 Even Sanudo recounts that on the 29 October, 1518, the Council of Ten had decided that "in Cypro si bati certa moneda ditta Garzia". Marin Sanudo, I diari, 58 vols. ed. Federico Stefani et al. (Venice: F. Visentini, 1889), 26: 152.

15 Edoardo Martinori, La moneta. Vocabolario generale (Roma: Istituto Italiano di Numismatica, 1915), p. 6o; Raffaele Paolucci, La zecca di Venezia II (Padua, 1991), p. 192. 
In any case, this remote origin does not help us to comprehend any better how the meaning of the term shifted from something related to a system of value or a coin, to a newssheet of events.

\section{The Newssheet}

For now, let us return to the newsletter and examine how the term began to propagate and with what meanings, and finally, consider if there is any means of distinguishing between avviso and gazzetta, often considered to be synonyms. In Italian, between the fifteenth and the first half of the sixteenth centuries, the term avviso was that most commonly used when referring to current events and to the sheets which reported them. ${ }^{16}$ During the same period, other words or expressions were used, such as nova/nuova (news), reporto (report), lettere (letters), sommario (summary), capitolo di nova (chapter of news). In all these cases, however, the same terms were used indiscriminately, each being used both in the general sense of 'news' and the specific sense of newssheet. It was almost impossible to distinguish between the object and its content. In the early 1500s, when Marin Sanudo, in his very detailed diary covering events in Venice between the years 1496 and 1533, wrote about the avisi that arrived in the city from all over the Mediterranean, he was referring to the news sent as part of normal correspondence or to specialised newssheets, which only contained specific types of information. The same was true for the works of other writers in the first half of the 150os, such as Niccolò Machiavelli, Francesco Guicciardini, Pietro Aretino and many others, all of whom used the term avviso in both its senses. Halfway through the century, the term avviso was still being used in related documents, such as ambassadorial dispatches and in the collections of newsletters, such as those of the Duke of Urbino or the Fuggerzeitungen, which began to be kept from around this time. Furthermore, the first descriptions of the profession of

This origin is also suggested by G. Boerio, Dizionario del dialetto veneziano (Venice, 1856), p. 302, entry gazeta. I owe the information gathered on the numismatic bibliography to Michele Asolati and Marco Callegari. The correspondence to the German Kreutzer is presumed by Justus Lipsius, Della grandezza di Roma et del suo imperio (Rome, 160o), p. 262.

16 On the word avviso and his derivations in the language of information see. Johann Petitjean, 'Mots et pratiques de l'information. Ce que aviser veut dire (XVIe-XVIIe siècles)', Mélanges de l'École française de Rome-Italie et Méditerranée, 122.1 (2010), pp. 107-21. On the use of the German Avisen interesting notes in the dissertation of Samuel Fridericus Hagen, De jure novellarum. Von Neuen Zeitungen (Kilonii [Kiel], 1697), p. 6. 
newswriting introduced no new terminology, any more than did the first pontifical acts against writers of defamatory libels or avvisi. The Constitution of 1572 "contra scribentes, dictantes ... libellos famosos et literas noncupatas de Avisi" (against those who write and dictate ... infamous libels and letters of avvisi) called the newssheets Literae monitorum vulgo appellatae lettere d'avisi (letters of warning, called by people avvisi). ${ }^{17}$

In the second half of the sixteenth century, the taking root and growth of the new profession of compiling handwritten newsletters also led to the fixing of names for the folios containing news. At the end of the 156 os the word gazzetta began to be recorded, but it continued for some decades to be primarily a term belonging to the spoken language, referring specifically to newssheets which lacked credibility which might circulate in the city. It is certain that the term began to be used in writing with the clear meaning of 'newssheet' towards the end of the 1570s. A document survives that may indicate an earlier usage of the term around 1568, when it seemed to appear in the title of a mock-heroic poem written and printed in the franco-provenzal dialect of Geneva, La gazeta de la guerra de zay, zay su zay, zay la vella et zay la Comba. ${ }^{18}$ However, this date is uncertain; the only existing specimen of this booklet is without a title page and bears a date which may refer to the period of the events it relates rather than its publication. This booklet refers to the fights between the French soldiers and the inhabitants of the small town of Gex, close to Geneva, in September 1568. It is therefore possible that the booklet was printed with the cited title years later, by which time the term had become widespread in Europe.

Instead, as previously mentioned, the word began to appear more and more frequently in Italy as of 1577. In that year the illustrious Florentine philologist Vincenzio Borghini used the term in his private correspondence, referring to an untrustworthy historian who recklessly used the text of a gazzette as a source of information to reconstruct an incident in the life of the Cardinal Giovanni de' Medici. ${ }^{19}$

From the 1580 s the term began to appear more and more often in Italian documents, in Rome, Florence, and Venice, invariably signifying a serial manuscript

17 Magnum Bullarium Romanum a Pio Quarto usque ad Innocentium (Lyon, 1673), vol. 9: 356-7, 17 March 1572; 363-4, 1 September 1572. On such constitutions Cornel Zwierlein, Discorso und Lex Dei, Die Entstehung neuer Denkrahmen im 16. Jahrhundert und die Wahrnehmung der französischen Religionskriege in Italien und Deutschland (Göttingen: Vandenhoeck \& Ruprecht, 2006), pp. 268-70.

18 This newssheet, lacking frontispiece, is in the British Library, shelfmark: T. 1589.

19 The letters of Vincenzio Borghini are in the Raccolta di prose fiorentine (Florence, 1745), vol. 4, p. 317 . 
containing political news. It can be to found in some Roman newssheets, in the dispatches of Venetian ambassadors, and in documents in the Medici's archive where there are references to avvisi sent from Venice. ${ }^{20}$ The context is always very similar. It speaks of avvisi and news within the gazzetta, of the authors of the gazette and of payments made for the sheets of information. It seems evident that the handwritten gazzetta had by that time become a public instrument of up-to-date information which the courts could not forgo, but which was also becoming more widespread within society. For the Tuscan poet, Giovan Maria Cecchi (1518-87), it is "a wicked witch, that goes around chatting on and on, and disrespectfully deceives all". ${ }^{21}$ Even at the time, the gazzetta had its professionals: those who did the writing, and those who took care of distribution and sales (not in the form of single copies, but in yearly or biannual series). Morever, documents referring to the gazetta make frequent mention of the fact that the information it contains is never completely reliable and never touches upon government affairs. It is important to note the capacity of the gazzetta, even at the time, to raise interest and attention among a growing urban audience.

On 21 July 1586 Francesco Vendramin, Venetian ambassador in Turin, wrote to the Venetian Inquisitori di Stato:

In proposito de i secreti di stato che sono palesati io le dirò per hora come ragionando qui col baron Sfondrato, ambasciator del re di Spagna, di diverse cose in certo proposito è trascorso a dirmi liberamente che dal Salazar agente di Sua Maestà Cattolica in quella città gli era ordinariamente assai ben avvisato di tutte le cose soggiongendo che non sono così da reporti della gazetta, ma molte volte de più importanti che si trattano ...22

(In respect of the secrets of state that have appeared, I will tell you for now with reasoning that baron Sfondrato, ambassador of the king of Spain, sends me diverse things to certain purpose, freely telling me that Salazar, the agent of His Catholic Majety in that city, was ordinarily

20 Biblioteca Nazionale Centrale di Firenze, Fondo Magliabechi, cl. xxIV, cod. 16, Rome 17 December 1588, also quoted in Enrico Stumpo, ed., La gazzetta de l'anno 1588 (Florence: Giunti editore, 1988), p. 171: "reporti della gazetta”; Archivio di Stato di Firenze, Mediceo del Principato, 2940, references to the "gazzetta di Venezia" in a letter from Marcello Donati to Pietro Usimbardi, 19 March 1588.

21 "La gazzetta è la mala strega/che va ciaramelando tanto tanto,/e che senza rispetto a ognun la frega". G.M. Cecchi, Poesie pubblicate per la prima volta da Michele dello Russo (Naples: Francesco Ferrante, 1866), p. $3^{2}$.

Archivio di Stato di Venezia, Inquisitori di Stato, b. 488, 21 July 1586. 
well-informed of all the things, adding that they are not reporti della gazetta, but many times more important things that you treat ...)

On that occasion, Vendramin was explaining that the information supplied by a Spanish agent in his court was news containing state secrets, very different from what was to be found in 'gazzetta reports'.

The diffusion of the term outside Italy must have been fairly rapid, being presumably contemporary with the diffusion of the information sheets themselves. Between the last decade of the sixteenth century and the first of the seventeenth the word gazzetta, in its local variations became common in England, France and Spain. In May 1596 Francis Bacon writes to his brother Anthony sending him a gazette:

15 May 1596

My very good Brother,

I have remembered your salutations to Sir Jh. Fortescue and delivered him the gazetta, desiring him to reserve it to read in his barge.

He acknowledged it to be of another sort than the common. I delivered him also so much of Dr. Hawkins letter as contained advertisements copied out, which is the reason I return the letter to you now; the gazetta being gone with him to the Court.

The refiner's conclusion I have not acquainted him with, meaning to keep it for more apt time.

So in haste I wish you comfort of Twicknam ague this $15^{\text {th }}$ of May, 1596

Your entire loving brother

Fr. Bacon ${ }^{23}$

And some days later:

My very Good Brother,

I send you the gazetta returned from Sir Jh. Fortescue with his loving commendations ...

In this case it must be of further significance that Bacon still uses the Italian term gazzetta rather than a matching English term or the anglicised word gazette. It is also interesting that the Henry Hawkins quoted in the letter was an

23 Francis Bacon, The Letters and the Life, ed. James Spedding, 7 vols. (London: Longman et al., 1862) 2: 32, letters to Antony Bacon 15 and 20 May 1596. 
English intelligencer employed in Venice who had sent secret information about the political situation. ${ }^{24}$

In the following years the term is also recorded in printed works of English writers, but consistently with reference to newssheets. In 1607 Ben Johnson writes in Volpone:

$\mathrm{O}$, I shall be the fable of all feasts,

The freight of the gazetti; ship-boy's tale;

And, which is worst, even talk for ordinaries.

And in 1611, Thomas Coryat documents in Crudities, an account of his journey through France, Italy and Germany in the year 1608: "For sure that Jew from Venice came, we finde it so recorded. In late Gazettas: which or lies, or trifles ne'er afforded". 25

In those same years the word was also known and diffused in Spain. In 1606 the Spanish historian and bishop of Tui Prudencio de Sandoval writes in his biography of the emperor Charles $\mathrm{V}$ about 'noveleros' and 'gazeteros' that "escriven y venden sin orden ni verdad, que tales son sus gazetas" (they write and sell without order and truth, such are their gazettes"). ${ }^{26}$ From that moment onwards, the use of the word becomes increasingly frequent in the hispanicised form gaceta.

The French situation is more complex. In 1603, a diplomat named Jean Hotman in the service of Henri IV writes of gazettes (in the French form of the word) that refer to affairs in Rome in his book L'ambassadeur. ${ }^{27}$ Some years later, Pierre de Rosteguy de Lancre, a magistrate of Bordeaux who was well acquainted with Italy, while speaking of talking statues in Rome and Venice, describes the very Italian habit of affixing pasquinades and satirical writings whose contents were spread "par le moyen de la gazette" ("by means of the gazette") "par tous les quatre coings de l'Europe" ("across all four quarters of Europe"). ${ }^{28}$ Another contemporary writer, Antoine de Laval, makes similar

24 On Henry Hawkins see Gustav Ungerer, A Spaniard in Elizabethan England. The correspondence of Antonio Perez's exile (London: Tamesis Books, 1976), vol. 2.

25 Thomas Coryat, Coryat's crudities: hastily gobled up in five moneths travells in France, Savoy, Italy, Rhetia (Glasgow: J. MacLehose \& sons, 1905), p. 52.

26 Prudencio de Sandoval, Segunda parte de la vida y hechos del Emperador Carlos Quinto (Valladolid, 1606), p. 679 .

27 Jean Hotman, L'ambassadeur (n. p., 1603), p. 41.

28 "Quelle folie en quel lieu que ce soit, de tenir ces statues de Bartholomeo Coglioni, di Marforio, de Pasquin et autres semblables, comme perrons de proclamations d'iniures, en une ville si saincte, ou en cest autre si réglée, où il y a des Sages de terre, et des Sages de 
remarks regarding the novellanti of Rome, Venice and the Place du Change in Paris, using the same language found in the gazette. ${ }^{29}$

At the same time, the title Gazette reappeared in many other types of compositions, mostly satirical or comic collections of stories, in verse or in prose, usually making some vague reference to the current political situation. Take, for example, the case of Marcelin Allard, merchant of Saint-Etienne, who in 1605 published a book written some years previously entitled La gazzette française where he collected in a haphazard manner, stories of various genres and assembled in random order. He defined his Gazzette as:

une formede saugrenée ou pot pourri, contenant toutessortes d'instructions et de discours agréables en leur diverses variétés, et riches en leur recherche curieuse: l'histoire admirable d'une guerre faite à tout rompre...${ }^{30}$

(a sort of stew or pot pourri, containing all sorts of instruction and pleasant accounts in all their different varieties, rich in carefully gathered information: the admirable history of a war to make all split ...)

This personal definition, adapted to his particular composition, does not indicate that the lacked a clear idea of what was intended by the term gazzetta in the French province between the end of the 1500 s and the beginning of the 160os. Allard and his readers knew perfectly well what they were dealing with. In fact, the book begins with a clear, though satiric, description of its normal functions:

Le Courier ordinaire de la Gazzette Françoise, voulant partir de ceste bonne ville de France, pour porter à Rome (en contre-escange de celles qu'il nous envoyent) des nouvelles toutes nouvelles, toutes fraichement escloses: nouvelles nouvellement nées et nouvellement tombées des nues ...31

mer, pour pallier et couvrir une mesdisance secrete? Pasquin couvre tousiours son autheur; mais il descouvre et publie l'iniure; et si elle est de bon rencontré par le moyen de la gazette, il la proclame par tous les quatre coings de l'Europe". Pierre de Lancre, Tableau de l'inconstance et instabilité de toutes choses ... Augmenté avec un livre nouveau de l'inconstance de toutes les nations (1607; Paris, 1610), p. 447.

29 Antoine de Laval, Desseins de professions nobles et publiques, contenans plusieurs traictés divers \& rares: avec l'histoire de la maison de Bourbon (1605; Paris, 1613), p. 338.

30 Marcellin Allard, La Gazzette française (Paris, 1605), p. 3. On Allard see Gerard Blanchard, 'La première gazette française', Communication et langagues, 17 (1973), pp. 66-81.

31 Allard, La Gazzette française, p. 1. 
(The ordinary courier of the French Gazette, wishing to leave this fair French town, in order to bring to Rome (in exchange for what they send us) of the newest of the new, freshly disclosed; news newly born and newly dropped from the clouds ...)

Other works produced during those years presented similar characteristics. In 1609 in Rouen, a short poem about the gazette was published, in which the anonymous author referred satirically to the characteristics and the functions of these kinds of newsletters. It described the various groups like magistrates, prelates and other office-holders who were the target public of the newssheets and underlined the rapidity with which the gazettes were able to gather information on various aspects of life and present them to this public, satisfying everybody's curiosity. ${ }^{32}$ From that time onward, the word became a current element of political language and European information, able to clearly define a written document with particular characteristics.

For now, we will return to the question posed beforehand as to whether or not there was, during those years, a difference between avviso and gazzetta or whether it really was, from the outset, a true synonym for avviso. Based on what little evidence is available and the way in which the term was habitually used, it would seem that at least until the early part of the seventeenth century the two words were not always used as synonyms. While avviso continued to be used in its traditional sense - that is to say, a regularly-published newssheet or the news which it contained - the meaning of gazzeta remained unclear. It could mean a newsletter, but it could also be any writing on vaguely newsworthy themes, not necessarily appearing at regular intervals. This is the case of the gazetta of Geneva mentioned above, but also of other publications. The Gazette des estats et de ce temps, which was printed and published in France in 1614 and presented in the guise of a translation from the Italian, was not a periodical but rather a pamphlet dealing with important questions of the time, such as France's possible adoption of the Tridentine decrees. ${ }^{33}$

32 "La gazette en ces vers/contente les cervelles/car de tout l'universe/elle reçoit nouvelles .../ Gazette aymée des prélats,/des princes et des magistrats:/gazette en vogue incomparable/ gazette en science admirable:/Car rien ne se fait, ne se dit,/rien ne va, ne vient par escrit,/en poste, en relaiz, en mazette,/qui ne passe par la gazette .../La gazette a mille courriers,/qui logent par-tout sans fouriers,/et faut que chacun luy responde,/selon sa course vagabonde,/ De ça de là diversement/De l'orient, en Occident,/et de toutes pars de la sphère,/sans laisser une seule affaire,/soit edicts, des commissions". Louis Loviot, ed., La Gazette de 1609 (Paris: Fontemoing, 1914).

33 Gazette des estats \& de ce temps. Du Seigneur servitour de Piera Grosa gio: Traduite d'Italien en François le premier janvier 1614. 
More generally, the term gazzetta, in all its variations in the many different European languages remained a term more in use in spoken than in written language, used in conversation and in correspondence and less often in formal or offical documents. In 1602, the Italian writer Tommaso Costo wrote about avvisi, which he said are commonly called gazette ${ }^{34}$ and in 1636 the historian Agostino Mascardi reiterated the concept and wrote "avvisi or should we use the more vernacular term gazzetta". ${ }^{35}$ This is probably why it did not appear in any monolingual dictionary of the first decades of the seventeenth century, which were apt to record entries with an elevated register with the aim of establishing a vernacular language with the same dignity as Latin. For this reason it does not appear in the Thrésor de la langue française by Jean Nicot (Paris, 16o6), nor in other French language dictionaries until the first edition of the Dictionnaire de l'Académie française published in 1694 where we can find the following definition:

GAZETTE. sub. f. Cahier, feüille volante qu'on donne au public toutes les semaines, \& qui contient des nouvelles de divers pays. Gazette de France, de Hollande. Gazette imprimée. Gazette à la main.

On appelle fig. Gazette, une personne qui est curieuse d'apprendre des nouvelles, \& qui les va publier par tout. Cette femme est dangereuse, c'est la gazette du quartier, c'est une vraye gazette.

(GAZETTE, sub. f. Booklet, flying sheet published weekly, and which contains news of various countries. Gazette of France, of Holland. Printed Gazette. Handwritten Gazette.

One refers figuratively to someone who is eager to learn news, and who spreads it around everywhere, as a Gazette. That woman is dangerous, she is the gazette of the neighbourhood, she is a true gazette.)

The same is true for the Italian. It is not mentioned in the first two editions of the Vocabolario degli Accademici della Crusca (Alberti 1612 and Sarzina 1623). Not until the third edition (1691) does the entry gazzetta appear where it is defined as a 'Foglio d'avvisi' with the now common explanation that the name was derived from "a certain type of coin which was used to buy avvisi". Similarly

34 "Lettere d'avvisi, chiamate volgarmente gazette". Tommaso Costo, Lettere (Venice, 1602), pp. 359-87.

Agostino Mascardi, Dell'arte istorica (1636; Florence: Felice Le Monnier, 1859), p. 225. 
in Spanish, where the term is not found in the Tesoro de la lengua castellana o española, of Sebastián de Covarrubias (Madrid, 1611). ${ }^{36}$

Bilingual dictionaries are a different matter, since these were works more sensitive to common usage and dialect expressions than to educated usage. Thus it is not surprising that the only sixteenth century dictionary that actually contained the word and its derivations was the Italian-English $A$ Worlde of Wordes by John Florio (1598), the son of an exiled Protestant from Florence who translated both Giordano Bruno and Montaigne into English, and was much more aware of the spoken language and of the words that came from dialect than of those that were part of formal, learned Italian. He offered a brief but precise definition of the plural form of the Italian words gazzette and of other related terms, gazzetta, gazzettare, gazzettiere:

GAZZETTA, a young pie or piot

GAZZETTE: the daily newes or intelligence written from Italie, tales, running newes.

GAZZETTARE: to write or report daily occurrences one to another, to tell flying tales

GAZZETTIERE: an intelligencer or such as have daily occurrences ${ }^{37}$

Florio's definition is very interesting because it was completely original compared to those which appeared years later in other dictionaries which we have cited, and it was able to show, very concisely and effectively, the status of the term at a time when both the term and the object itself were being established. In this case the as yet ill-defined relation between espionage and information was explicitly mentioned, as was the Italian origins of the news. Substantially the same meaning was attributed to the term gazzettiere, while the meaning of the singular form of the word gazzetta was given as a young magpie. The fact that Florio was well aware of the way in which the meaning of words could evolve is clear from the way he added further detail to the entry gazzette in the second edition of the dictionary published in 1611. However, it was evidently in those very years that the use of such sheets began to spread beyond court circles, so that Florio added to his previous definition the words "flim flam tales that are daily written from Italie, namely from Rome and Venice". The role of the gazzettiere himself was also

36 For the consultation of the various dictonaries, I used mostly on-line data: for the French: $<$ artfl-project.uchicago.edu/node/17>; for the Italian: < vocabolario.sns.it/html/_s_index2. html $>$; for the Spanish: <www.rae.es/recursos/diccionarios $>$ [8/04/15]. 
changing. He ceased to be an "intelligencer" and became simply a "writer or reporter of gazette". Florio also made slight corrections to two other entries: Gazzettare became "to chat as a magot a pie. Also to write or report Gazzette" and to the entry Gazzetta, he added "also a coine in Italie". ${ }^{8}$

John Florio's definitions illustrate well the ambiguities surrounding the newssheets, which evolved from being documents of secret information read in seats of power into news-letters specially written for a public readership. The gazetteer, originally part copyist and part spy and in any case dealing only with court circles, ambassadors' chancelleries and prominent figures in European capitals, increasingly managed to forge new relationships with a widening readership, allowing for the formation of a veritable market for information.

In the following years other bilingual European dictionaries also began to record the definition. It was found in Florio's Italian-English dictionary and Cotgrave's French-English dictionary. It was the same for Franciosini's ItalianSpanish dictionary in 1620 and in various others. ${ }^{39}$

\section{Conclusion}

In principle, the way in which the two terms - avviso and gazetta - developed reflects the evolution of the media. One can clearly state that the sixteenth century was the age in which the avviso underwent its most significant transformation. It evolved from a generic report on a fact or an event, into a welldefined product designed to satisfy the growing demand for specific information emerging in certain circles in the more important political and commercial centres of the time. This growing demand for news hastened the development of a 'market' for news and information that could be supplied on a regular basis for more general consumption and that was no longer reserved for specific spheres. Even though a gazette continued to be a handwritten document for a long time, it was the avviso that was able to enlarge its sphere of

38 Queen Anna's New World of Words or dictionarie of the Italian and English tongue (London, 1611), p. 205. About the dictionary of John Florio, see Frances A. Yates, John Florio: The life of an Italian in Shakespeare's England (Cambridge: Cambridge University Press, 1934), pp. 188-212, and Michael Wyatt, The Italian Encounter with Tudor England: A Cultural Politics of Translation (Cambridge: Cambridge University Press, 2005).

39 "Gazzetta o avviso che si manda da un luogo ad un altro, che tratta il più delle volte di quello che ha sognato colui che lo scrive o di quello che fanno o pensan di fare i principi". Lorenzo Franciosini, Vocabolario italiano, e spagnolo non più dato in luce (Rome: Gio. Angelo Ruffinelli \& Angelo Mann, 1620). 
readers and arouse interest in political events in the new urban setting of the time. Moreover, the growing good fortune of the printed gazette throughout Europe during the seventeenth century did not put an end to the issuing of manuscript avvisi, which retained their designation and which, up until the end of the 170os, continued to carry out their function as an instrument of information reserved especially for those in power.

There remains only to clarify the semantic shift which led the newssheet to assume the name of a low valued coin within a well-defined span of time, sometime between 1560 and 1570 . Due to a lack of direct documentation of this change, our only remaining option is to introduce a hypothesis that recalls what was previously said: more precisely, the capacity of the gazzetta to involve a wider audience and become an object of market value compared to the avviso - although both continued to be handwritten. This capacity for public involvement was obviously frowned upon and became a frequent motive for criticism. A satirical booklet written in Rome around $155^{\circ}$ stated plainly that "news are things for ambassadors, great men and government men" and not for the general public or "foolish plebians" and continued to rant about the improperness of its diffusion. ${ }^{40}$

Obviously the mistrust towards works and texts which were subject to ample public consumption was not stricly limited to newssheets. Something similar happened each time a cultural product conceived for use by the higher levels of society began to broaden its audience. Such was the case in the world of theatre: one who was attached to the idea of the cultured, noble and courtly profession of acting did not appreciate the 'actor for sale' who offered his services to the public in the town squares. In this context, in 1585 , Tommaso Garzoni's extraordinary catalogue of all the professions of his age (La piazza universale di tutte le professioni del mondo) offered an elaborate description of the various activites linked to the theatre. There is no lack of characterization of charlatans and street histrions who frequently populated the urban scene in Italy at the time. In such depictions, the word gazzetta appears often, in the monetary sense but in particular expressions that merit special attention: the public had to pay a few gazzette to see the shows; at the end of each show, there were those who were responsible for collecting the gazzette; if the show was well-received, the actors were rewarded with gazzette. The payment in gazette thus seems to be a characteristic of street performers, to the point where it became a disparaging connotation of the profession. This affirmation is confirmed by another declaration a few years later. In 1592 Battista Guarini,

40 Mattio Franzesi, Capitolo sopra le nuove a M. Benedetto Busini, in Francesco Berni, Il secondo libro delle opere burlesche (Florence, 1555), pp. 58-9, UstC 814148. 
famous author of the poem Il pastor fido (The Faithful Shepherd) published the Verato, a book against the detractors of his poem, in which the word gazzetta is present repeatedly, but always in expressions like "istrioni della gazzetta", "commedianti della gazzetta", "commedia della gazzetta" (historians of the gazette, third-rate actors of the gazette, comedy of the gazette). ${ }^{41}$

The cross-reference to the theatre is interesting and may be able to explain how the meaning of the word gazzetta evolved from a coin to a newssheet or at least offer some hypothesis on the subject. In the sixteenth century the Italian piazzas were animated by charlatans, ballad singers, buffoons, who on the occasions of fairs entertained the public "improvising and singing of battles and romance, reciting dialogues and comedies, narrating novella". Very frequently these street performers sold booklets and broadsheets concerning their performances, as can be found in various engravings of the era. ${ }^{42}$

We are in the same era in which the handwritten newsletters were propagating in the most important cities, such as Venice, Florence and Rome. It is plausible that the two products with similar features were assimilated and that the gazzetta, then a current coin of low value, tended to identify them-at least that was the intention of many who were inclined to discredit the sheets which reported notorious and unsubstantiated news.

This could explain the poor reputation that characterises all the early attempts to define the new object, as we read in Florio's dictionary and in many other cited documents. The negative connotations for the term gazzetta and its various derivations, strongly linked to its origins, still remains in many European languages.

41 Battista Guarini, Il Verato secondo, ovvero Replica dell' Attizzato (Florence: F. Giunti, 1593), pp. 733-44, USTC 834905. A riguardo see Laura Riccò, La miniera accademica. Pedagogia, editoria, palcoscenico nella Siena del Cinquecento (Rome: Bulzoni, 2002), pp. 129-30; Lisa Sampson, Pastoral Drama in Early Modern Italy: The Making of a New Genre (London: Legenda, 2006), p. 132. Many thanks to Franco Vazzoler for the details provided regarding the profession of acting.

Rosa Salzberg, "The Lyre, the Pen and the Press: Performers and Cheap Print in Cinquecento Venice', in The Books of Venice, ed. Craig Kallendorf and Lisa Pon Pon (New Castle, DE: Oak Knoll Press, 2008), p. 251, and 'In the Mouth of Charlatans: Street Performers and the Dissemination of Pamphlets in Renaissance Italy', in Renaissance Studies, 24 (2010), pp. 638-53; Laura Carnelos, Con libri alla mano: L'editoria di larga diffusione a Venezia tra Sei e Settecento (Milan: Unicopli, 2012). 